\title{
10. PALEOENVIRONMENTAL SIGNIFICANCE OF SILICEOUS SPONGE SPICULES FROM SITES 627 AND 628, LITTLE BAHAMA BANK, OCEAN DRILLING PROGRAM LEG 101 ${ }^{1}$
}

\author{
Amanda A. Palmer ${ }^{2}$
}

\begin{abstract}
Siliceous sponge spicules occur in deposits of Oligocene to Miocene age from Sites 627 and 628 , north of Little Bahama Bank, Bahamas. Spicules are abundant in only two cores from Site 627 (Cores 101-627B-18X and 101-627B-19X, early to middle Miocene age), but are the predominant siliceous component in six cores from Site 628 (Cores 101-628A$14 \mathrm{H}$ through 101-628A-19H, late Oligocene to middle Miocene age). Previous studies of siliceous sponge spicules recovered from Deep Sea Drilling Project sites were used to indicate paleobathymetry, evidence of redeposited shallow-water material, and general stratigraphic position.

The most obvious and potentially valuable aspect of siliceous spicule distribution is that the two main groups, tetraxons and triaxons (hexactinellids), are formed by sponges most abundant in shallow $(0-400 \mathrm{~m})$ and deeper $(>400$ $1000 \mathrm{~m}$ ) waters, respectively. The predominance of tetraxonal spicules in samples from Sites 627 and 628 suggests origin from, as well as deposition in, relatively shallow waters. The presence of triaxonal (hexactinellid) spicules in samples from Site 627 and the Oligocene of Site 628 indicates slightly deeper conditions and/or less influx of periplatform material during deposition of those intervals. Spicules were also examined from the Miocene section at a nearby deep basin site (Site 534, Blake-Bahama Basin), and triaxonal (hexactinellid) spicules were consistently present.
\end{abstract}

\section{INTRODUCTION}

This paper documents the siliceous sponge spicule assemblage from the upper Oligocene and Miocene of Sites 627 and 628, Little Bahama Bank (Fig. 1). Spicule occurrence at Site 534 (Blake-Bahama Basin) is also discussed.

Siliceous sponge spicules were first described from marine sediments in the 19th century (as noted by O'Connell, 1919; Pokorny, 1963; Ivanik, 1983). More recently, spicules have been recovered from Deep Sea Drilling Project sites (Bukry, 1978, 1979, 1980a, 1980b; Martini, 1982; Ivanik, 1983; Locker and Martini, 1986). The consensus of these recent studies is that sponge spicules do not generally provide detailed biostratigraphic data, but may be useful for interpreting paleobathymetry, and particularly for identifying shallow (warmer) waters $(<400 \mathrm{~m})$ vs. deep (colder) waters $(>400 \mathrm{~m}$ ) and for recognizing redeposited shallow-water materials. This application is of particular interest in regard to studies of Little Bahama Bank, an accretionary carbonate-platform margin on which periplatform deposition is significant (Austin, Schlager, et al., 1986).

\section{PROCEDURES}

The samples studied were originally selected from siliceous intervals of the cores for radiolarian studies (sample size is $10 \mathrm{~cm}^{3}$ ). Conventional radiolarian preparation procedures were followed (Riedel and Sanfilippo, 1977), including disaggregation of the samples in hydrogen peroxide solution, treatment with hydrochloric acid to remove calcium carbonate, and washing through a $63-\mu \mathrm{m}$ mesh sieve. An ultrasonic probe was used to disaggregate highly indurated samples from Site 534 when conventional procedures failed.

Strewn slides of the sieve residue were made for each sample and were scanned at $250 \times$ with a petrographic microscope. Qualitative estimates of spicule abundance were based on a survey of the entire $(20 \times$ $40 \mathrm{~mm}$ ) slide area. Figures 2 and 3 indicate relative spicule abundance based on these estimates.

\footnotetext{
${ }^{1}$ Austin, J. A., Jr., Schlager, W., et al,, 1988. Proc. ODP, Sci. Results, 101:
} College Station, TX (Ocean Drilling Program).

2 Ocean Drilling Program, Texas A\&M University, College Station, TX 77843.

\section{SPONGE VS. SPICULE CLASSIFICATION}

A detailed review of sponge or spicule classification is beyond the scope of this paper, although a few general remarks are necessary as introduction. Sponges consist of both skeletal and cellular material; the latter decomposes rapidly upon death of the organism, but the skeleton, composed of spongin fibers and calcareous or opaline spicules, resists decay (Rützler and Macintyre, 1978). The spongin eventually is degraded by bacterial action over a period of weeks or months, freeing the mineralized spicules, which are incorporated into the sediment. The siliceous spicules studied here are of two types: megascleres (larger skeletal elements, $>100 \mu \mathrm{m}$ in length, existing either free or as part of a framework) and microscleres (smaller, 10-110 $\mu \mathrm{m}$, always occurring as free elements). These siliceous spicules are formed of concentric layers of opaline silica, built around a hollow axial canal that originally contained organic material (O'Connell, 1919).

Spicules are classified according to various aspects of their geometry. The suffix "-axon" refers to the number of axes in the spicule, while "-actine" refers to the number of rays. The most common number of axes are one (monaxon), three (triaxon), and four (tetraxon) (Rützler and Macintyre, 1978). The number of axes is the fundamental basis for classifying spicules because this number reflects an important aspect of sponge skeletal organization. The siliceous sponges are divided into two main classes: the Desmospongiae and the Hexactinellida (Hartman et al., 1980). The desmosponges (reef sponges) are characterized by monaxonal and tetraxonal spicules. Only the hexactinellids (also called hyalosponges, or deep-sea glass sponges) contain triaxonal spicules and may contain other types of spicules (Rützler and Macintyre, 1978). Because a sponge may contain more than one type of spicule, and spicule types may occur in different orders (and even different classes) of sponges (Hartman et al., 1980), a specific type of spicule does not indicate a unique species or genus of sponge, although it may indicate a particular class or order in some cases. Features such as the number of rays allow subdivision of spicule types (see O'Connell, 1919, for a discussion).

The exclusive occurrence of triaxonal spicules in hexactinellid sponges allows hexactinellids to be positively identified in a 


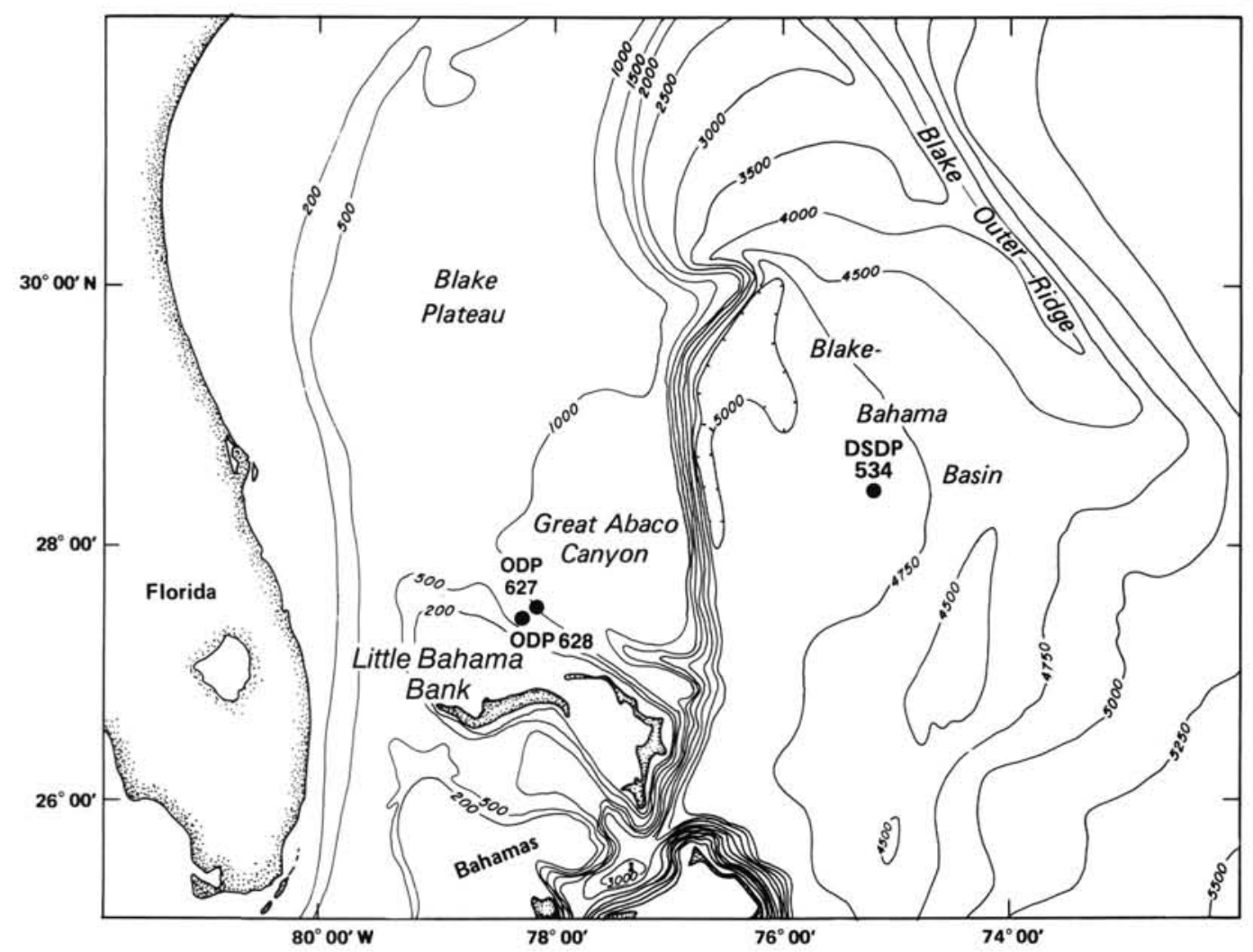

Figure 1. Map of Little Bahama Bank region, eastern North Atlantic Ocean, showing locations of Site 627, 628, and 534. Ocean bottom contours in meters.

spicule assemblage. Hexactinellids most typically live in deep water $(>1000 \mathrm{~m})$ and occur at shallow depths $(<100 \mathrm{~m})$ only in the frigid waters under Antarctic ice (de Laubenfels, 1957a, 1957b; Reid, 1968). Thus, triaxonal (hexactinellid) spicules in an assemblage indicate deep water. Although tetraxons may occur at all depths, hexactinellids are almost always absent at shallow depths. This provides a valuable tool for evaluating paleodepths in a setting such as the Little Bahama Bank transect.

\section{Spicules from Sites 627 and 628, Little Bahama Bank, and Site 534, Blake-Bahama Basin}

Figure 1 shows the location of Sites 627 (1028 m water depth) and 628 (966 m water depth) north of Little Bahama Bank, and Site 534 (4973 m water depth) in the Blake-Bahama Basin. Figures 2 and 3 illustrate the distribution of spicule types in samples from these sites. An annotated list of spicule types appears in the Appendix. Spicules are illustrated in Plates 1 through 4.

\section{Site $627\left(27^{\circ} 38.1^{\prime} \mathrm{N}, 78^{\circ} 17.65^{\prime} \mathrm{W}\right)$}

Sponge spicules occur in Cores 101-627B-18X and 101-627B19X (162.2-181.4 meters below the seafloor (mbsf)). These cores contain the following lithologies:

$162.2-164.4 \mathrm{~m}$ $164.4-171.8 \mathrm{~m}$ $171.8-179.8 \mathrm{~m}$

$179.8-181.4 \mathrm{~m}$
Packstone/graded beds (middle Miocene) Unrecovered (inferred hiatus)

Floatstone with green siliceous mud clasts (lower Miocene)

Firm, spicule-bearing calcareous ooze (lower Miocene).
As estimated by shipboard biostratigraphy (see Austin, Schlager, et al., 1986) and shore-based radiolarian studies (Palmer, this volume), this interval spans 7 m.y., including a 3-m.y. hiatus.

Three samples from Site 627 were studied in detail: Sample 101-627B-18X-1, 60-62 cm (middle Miocene packstone), Sample 101-627B-19X-2, 21-23 cm (lower Miocene green siliceous mudstone clast from a debris flow), and Sample 101-627B-19X, CC, $20-22 \mathrm{~cm}$ (lower Miocene calcareous ooze). Although tetraxonal spicules predominated in all of the samples, triaxonal spicules (mostly dictyonine fragments) were consistently present (Plate 4, Figs. 1 and 2). In the middle Miocene packstone, calthrops (as shown in Plate 1, Fig. 1, from Site 628) were the major spicule type. In both the lower Miocene mudstone (clast) and ooze interval, calthrops, plagiodichotriaenes, and monaxons (particularly oxeas and strongyles) were abundant. Another important group of objects that occurs in the ooze consists of branching and network structures, which appear to be sponge debris (possibly lyssacine fragments). Axial canals, present in sponge but not radiolarian skeletons, occasionally are observed in these objects (as shown in Plate 3, Fig. 4, from Site 628). However, some of these objects do not appear to have axial canals, and thus bear a strong resemblance to orosphaerid radiolarian fragments (see discussion in Palmer, this volume). In particular, digitately branched spines (Plate 3, Figs. 2 and 3) are characteristic of the middle Miocene orosphaerid radiolarian genus Oroscena (Friend and Riedel, 1967). Confusion between sponge and orosphaerid materials has long been a problem, starting with Haeckel's work on samples from the Challenger expedition of the late 19th century (Ivanik, 1983).

The presence of triaxonal (hexactinellid) spicules indicates the basinal setting that has characterized Site 627 since at least 


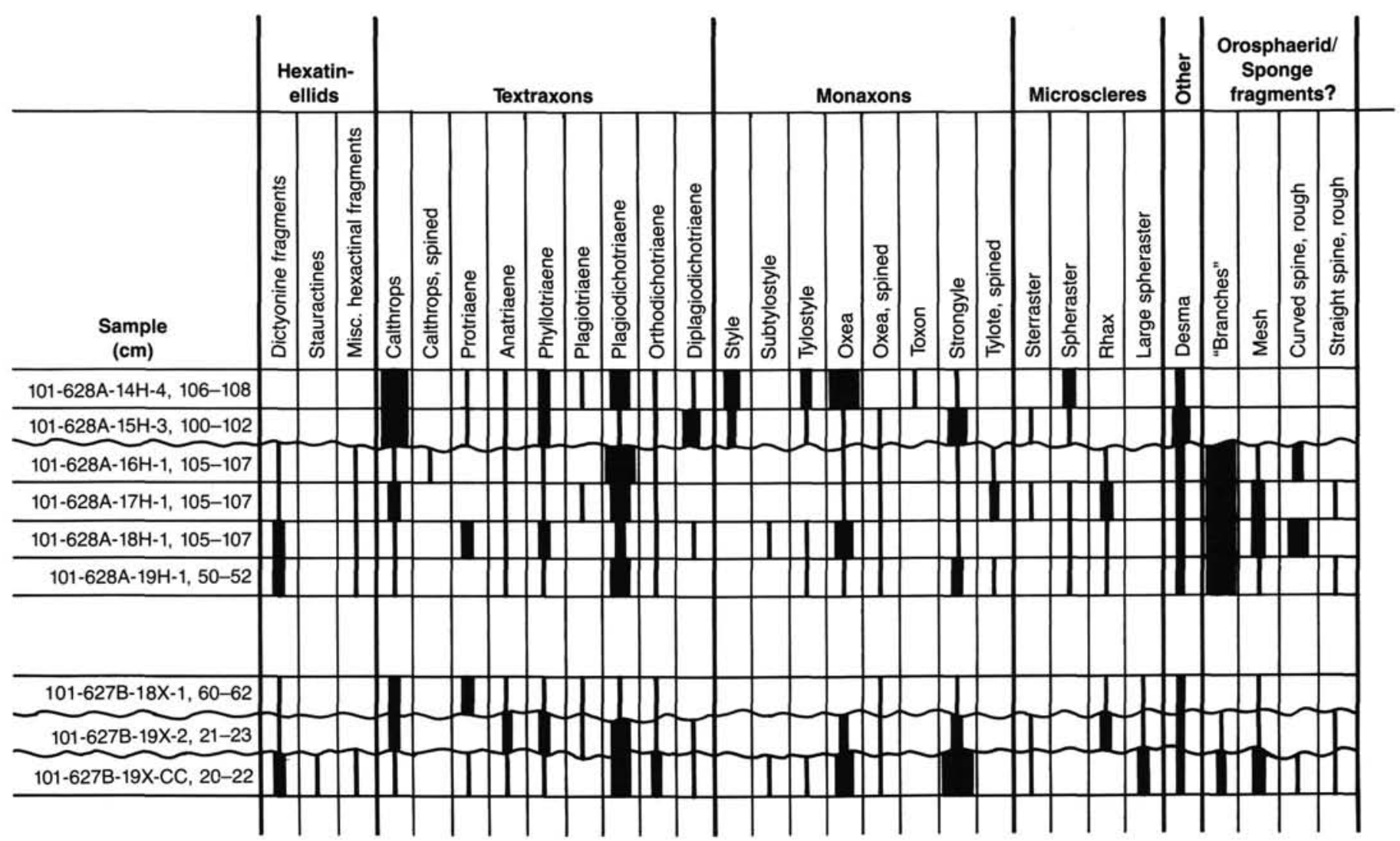

Figure 2. Occurrence of spicule types at Sites 627 and 628. Width of bar indicates relative abundance as determined by visual estimation. Widest to narrowest indicates abundant, common, few, or rare. Horizontal wavy lines indicate apparent unconformities, based on radiolarian biostratigraphy (Palmer, this volume).

the early Miocene. However, the abundance of tetraxonal spicules suggests significant influx of periplatform material.

\section{Site $628\left(27^{\circ} 31.85^{\prime} \mathrm{N}, 78^{\circ} 18.95^{\prime} \mathrm{W}\right)$}

Sponge spicules occur in Cores 101-628A-14H through 101628A-19H (117.4-170.6 mbsf). These cores contain the following lithologies:

\section{4-136.6 m Periplatform ooze (abundant micrite) (middle Miocene) \\ 136.6-170.6 m Foraminifer-nannofossil ooze $(<5 \%$ micrite) (upper Oligocene) \\ (170.6-183.2 m Unrecovered).}

As estimated by shipboard biostratigraphy (see Austin, Schlager, et al., 1986) and shore-based radiolarian studies (Palmer, this volume), the recovered interval spans $13 \mathrm{~m} . \mathrm{y}$., including a 10-m.y. hiatus.

Six samples from Site 628 were examined: Samples 101-628A$14 \mathrm{H}-4,106-108 \mathrm{~cm}$, and 101-628A-15H-3, 100-102 cm (middle Miocene periplatform ooze), and Samples 101-628A-16 H-1, 105$107 \mathrm{~cm}, 101-628 \mathrm{~A}-17 \mathrm{H}-1,105-107 \mathrm{~cm}, 101-628 \mathrm{~A}-18 \mathrm{H}-1,105-$ $107 \mathrm{~cm}$, and 101-628A-19H-1, 50-52 cm (Oligocene foraminifer-nannofossil ooze). All the spicules in the middle Miocene calcareous ooze are tetraxons and monaxons. The major types are calthrops (Plate 1, Fig. 1), plagiodichotriaenes, diplagiodichotriaenes (Plate 2, Fig. 4), desmas and monaxons (particularly styles, oxeas, and strongyles; Plate 1, Fig. 1). The Oligocene foraminifer-nannofossil ooze contained abundant tetraxonal spicules, with plagiodichotriaenes most abundant (Fig. 2). The predominant form, however, is the branching and network structures (as seen at Site 627) that may be either lyssacine sponge debris or orosphaerid radiolarian fragments (see previous discussion; Fig. 2). In addition, a few dictyonine (triaxonal, or hexantinellid) fragments were observed in the Oligocene samples.

These assemblages indicate slightly shallower water depths and greater periplatform influx during the Miocene than during the Oligocene at Site 628 , although probably not as deep as during the early Miocene at Site 627. These interpretations are generally consistent with results from benthic foraminifers (A. Melillo, pers. comm., 1986) and ostracodes (Guernet and Fourcade, this volume).

\section{Site 534}

A total of 29 samples were obtained for studying radiolarians (see Palmer, this volume) from the Miocene section of Site 534 (4971 m water depth). Spicules were consistently present, as indicated in Figure 3. A complicating factor (discussed in Palmer, this volume) is that a significant component of reworked Eocene siliceous material appears in debris flows and intraclastic chalks and mudstones throughout the Miocene interval. While tetraxons and monaxons are the predominant spicule types, and are similar to those at Sites 627 and 628, triaxonal spicules are more consistently present in samples from Site 534 than from the former two sites. However, as indicated in Figure 3, triaxonals are more abundant in the intervals containing redeposited Eocene material, suggesting that they are more characteristic of the Eocene sponge spicule assemblage of the source material than the Miocene of Site 534. Nevertheless, triaxons appear in the in-situ siliceous mudstone intervals consistently, indicating a 


\begin{tabular}{|c|c|c|c|}
\hline $\begin{array}{l}\text { Sample } \\
\text { (cm) }\end{array}$ & Lithology & $\begin{array}{l}\text { Hexactinellids } \\
\text { R F C }\end{array}$ & $\begin{array}{l}\text { Reworked } \\
\text { Eocene } \\
\text { radiolarians }\end{array}$ \\
\hline \multicolumn{4}{|l|}{$534 A-2-1,120-122$} \\
\hline \multicolumn{4}{|l|}{$534 A-4-2,80-82$} \\
\hline \multicolumn{4}{|l|}{$534 A-4-3.96-98$} \\
\hline \multicolumn{4}{|l|}{$534 A-4-4,60-62$} \\
\hline \multicolumn{4}{|l|}{$534 A-4-5,24-30$} \\
\hline \multicolumn{4}{|l|}{$534 A-5-2,60-62$} \\
\hline \multicolumn{4}{|l|}{$534 \mathrm{~A}-5-3,91-91$} \\
\hline $534 A-6-1,80-82$ & \multirow{3}{*}{$\begin{array}{l}\text { Intraclastic } \\
\text { chalk }\end{array}$} & & * \\
\hline $534 A-6-2,80-82$ & & & * \\
\hline $534 A-6-3,80-82$ & & & * \\
\hline \multicolumn{4}{|l|}{$534 A-7-1,104-106$} \\
\hline \multicolumn{4}{|l|}{$534 A-7-3,74-76$} \\
\hline \multicolumn{4}{|l|}{$534 A-7-5,40-42$} \\
\hline \multicolumn{4}{|l|}{$534 \mathrm{~A}-10-2,23-25$} \\
\hline \multicolumn{4}{|l|}{$534 A-11-2,52-54$} \\
\hline \multicolumn{4}{|l|}{$534 A-11-3,28-30$} \\
\hline \multicolumn{4}{|l|}{$534 \mathrm{~A}-12-2,97-99$} \\
\hline $534 A-12-4,60-62$ & \multirow{3}{*}{$\begin{array}{c}\text { Siliceous } \\
\text { mudstone } \\
\text { with } \\
\text { mudstone } \\
\text { chips }\end{array}$} & & * \\
\hline $534 A-12-5,60-62$ & & & * \\
\hline $534 \mathrm{~A}-13-1,78-80$ & & & * \\
\hline $534 A-13-2,45-47$ & \multirow{3}{*}{$\begin{array}{l}\text { Debris } \\
\text { flow }\end{array}$} & & * \\
\hline $534 \mathrm{~A}-13-3,28-30$ & & & * \\
\hline $534 A-13-3,76-78$ & & & * \\
\hline \multicolumn{4}{|l|}{$534 A-14-1,58-60$} \\
\hline \multicolumn{4}{|l|}{$534 A-14-2,86-88$} \\
\hline \multicolumn{4}{|l|}{$534 \mathrm{~A}-14-3,98-100$} \\
\hline $534 A-15-1,91-93$ & Intraclastic & & * \\
\hline $534 A-16-1,65-67$ & chalk & & * \\
\hline $534 A-16-2,64-66$ & & & * \\
\hline
\end{tabular}

Figure 3. Abundance of hexactinellids (free triaxons and framework skeletal fragments) at Site 534; occurrence of intraclastic chalks and debris flows, and reworked Eocene radiolarians (after Palmer, this volume) also indicated.

Miocene deep-water setting consistent with the basinal location of Site 534.

\section{PALEOECOLOGICAL INTERPRETATION}

Siliceous sponge spicules provide the basis for a paleoecological interpretation of the Oligocene and Miocene carbonate plat- form flank deposits north of Little Bahama Bank. Sponges require relatively clear, nonturbid water as living conditions because muddy waters clog their pores. At Site 627, the lower Miocene firm, spicule-bearing ooze probably accumulated in deep, quiet, nonturbid waters; spicules from bottom-dwelling sponges were incorporated into a background "rain" of calcare- 
ous pelagic sediment. Spicules in the overlying Miocene debrisflow interval probably come from the green mud clasts (and therefore reflect depositional conditions of the mud); this was most likely similar to that of the firm ooze. Debris flows would probably prove fatal to sponges in the vicinity. The Miocene packstone with graded beds is an improbable lithology in which to find spicules, as the turbidity currents that produced these graded beds would not be conducive to sponge development. Most likely spicules in this interval were transported from the banks and redeposited by the turbidity currents. Thus it appears that only the spicules in the firm ooze were from in-situ sponges; the rest were probably redeposited. Similarly, at Site 628 the Oligocene foraminifer-nannofossil ooze probably represents the accumulation of spicules from in-situ sponges and background pelagic sedimentation. The overlying Miocene periplatform ooze contains a larger proportion of redeposited material from the bank (i.e., micrite), and the more turbid depositional setting could have been less conducive to sponge growth. The foraminifer-nannofossil ooze contains some deep-sea glass sponge debris, indicating relatively deep conditions and/or less periplatform input, while the predominance of shallow-water reef-type sponge spicules in the overlying periplatform ooze supports the interpretation of a relatively shallow depositional environment and/or more periplatform influx. The middle Miocene packstone, lower Miocene siliceous mudstone (clast), and lower Miocene firm ooze at Site 627 all contain more fragments of deepsea glass sponges than were observed at Site 628 , which suggests a deeper setting and/or less platform input, assuming that presentday water depths reflect relative Miocene water depths at these sites. As the Bahamas are not believed to have experienced any major tectonic movements since the Miocene, this assumption appears reasonable. This model is supported by the spicule assemblage from basinal Site 534, where deep-water spicules form a significant component (approximately 1\%-10\%) of the assemblage.

Sponge spicules promise to yield paleoenvironmental information at other ODP sites and may be particularly informative on slope transects.

\section{ACKNOWLEDGMENTS}

I appreciate the assistance of the ODP curatorial staff and the East Coast Core Repository in obtaining samples from DSDP Site 534. Peggy Myre helped with sample preparation and photography; Frank Rack also prepared samples. Artwork was drafted by Jean Bettenhausen. I appreciate reviews by J. Austin, D. Bukry, J. Pickett, and W. Schlager.

\section{REFERENCES}

Austin, J. A., Jr., Schlager, W., et al., 1986. Proc. ODP, Init. Repts., 101: College Station, TX (Ocean Drilling Program).

Bukry, D., 1978. Cenozoic coccolith, silicoflagellate, and diatom stratigraphy, Deep Sea Drilling Project Leg 44. In Benson, W. E., Sheridan, R. E., et al., Init. Repts. DSDP, 44: Washington (U.S. Govt. Printing Office), 807-863.

1979. Coccolith and silicoflagellate stratigraphy, northern MidAtlantic Ridge and Reykjanes Ridge, Deep Sea Drilling Project Leg 49. In Luyendyk, B. P., Cann, J. R., et al., Init. Repts. DSDP, 49: Washington (U.S. Govt. Printing Office, 551-581.

1980a. Eocene diatoms and siliceous sponge spicules from the northwestern Atlantic Ocean, DSDP Sites 417 and 418. In Donnelly, T., Francheteau, J., Bryan, W., Robinson, P., Flower, M., Salisbury, M., et al., Init. Repts. DSDP, 51, 52, 53: Washington (U.S. Govt. Printing Office), 851-855.

1980b. Silicoflagellate biostratigraphy and paleoceanography in the eastern equatorial Pacific, Deep Sea Drilling Project Leg 54. In Rosendahl, B. R., Hekinian, R., et al., Init. Repts. DSDP, 54: Washington (U.S. Govt. Printing Office), 545-573.

Friend, J. K., and Riedel, W. R., 1967. Cenozoic orosphaerid radiolarians from tropical Pacific sediments. Micropaleontology, 13:217232.
Hartman, W. D., Wendt, J. W., and Widenmayer, F., 1980. Living and fossil sponges: notes for a short course. Sedimenta VIII.

Ivanik, M. M., 1983. Paleogene and Neogene sponge spicules from Sites 511, 512, and 513 in the South Atlantic. In Ludwig, W. J., Krasheninnikov, V. A., et al., Init. Repts. DSDP, 71 (Pt. 1): Washington (U.S. Govt. Printing Office), 933-950.

de Laubenfels, M. W., 1957a. Marine sponges. Treatise on Marine Ecology and Paleoecology, Vol. 1. Geol. Soc. Am. Mem., 67:1083-1086. , 1957b. Sponges of the post-Paleozoic. Treatise on Marine Ecology and Paleoecology, Vol. 2. Geol. Soc. Am. Mem., 67:771772.

Locker, S., and Martini, E., 1986. Silicoflagellates and some sponge spicules from the southwest Pacific, Deep Sea Drilling Project Leg 90. In Kennett, J. P., von der Borch, C. C., et al., Init. Repts. DSDP, 90: Washington (U.S. Govt. Printing Office), 887-924.

Martini, E., 1982. Pliocene and Quaternary diatoms, silicoflagellates, sponge spicules and endoskeletal dinoflagellates from the Philippine Sea, Deep Sea Drilling Project Legs 59 and 60. In Hussong, D. M., Uyeda, S., et al., Init. Repts. DSDP, 60: Washington (U.S. Govt. Printing Office), 565-574.

O'Connell, M., 1919. The Schrammen collection of Cretaceous Silicispongae in the American Museum of Natural History. Bull. Am. Mus. Nat. Hist., 41:1-261.

Pokorny, V., 1963. Porifera. Principles of Zoological Micropaleontology, 2:1-25.

Reid, R.E.H., 1968. Bathymetric distributions of Calcarea and Hexactinellida in the past and present. Geol. Mag., 105:546-559.

Riedel, W. R., and Sanfilippo, A., 1977. Cainozoic Radiolaria. In Ramsay, A.T.S. (Ed.), Oceanic Micropaleontology: London (Academic Press), 847-912.

Rützler, K., and Macintyre, I. G., 1978. Siliceous sponge spicules in coral reef sediments. Mar. Biol., 49:147-159.

Date of initial receipt: 14 November 1986

Date of acceptance: 16 August 1987

Ms 101B-130

\section{APPENDIX}

The following list is not exhaustive but does describe the significant spicule types observed in samples from Sites 627 and 628.

\section{CLASS HYALOSPONGIAE}

Order Hexactinellida

Group Dictyonina

dictyonine fragments (Plate 4, Figs. 1 and 2)

These fragments appear as two or more hexactinal spicules fused at the tips of the rays to form a lattice.

\section{Group Lyssacina}

macroscleres

hexactines

Individual hexactinal spicules.

stauractines

Four-rayed hexactinal spicules in which rays in the third axis are reduced.

\section{CLASS DESMOSPONGIAE}

\section{Order Tetraxonida}

Tetraxons

calthrops (Plate 1, Fig. 1)

Tetraxonal spicules in which three rays of equal length (not necessarily in the same plane) meet at $120^{\circ}$; the fourth ray is reduced and points in the opposite direction; rays may be smooth or spined.

protriaene

Three equal-length rays point away from a longer main spine and curve toward one another.

anatriaene

Three equal-length rays are directed back toward a longer main spine.

phyllotriaene (Plate 2, Figs. 1 and 2)

An irregular plate (or shape derived from a plate) that 
may have rudimentary axial canals meeting at $120^{\circ}$ in the center.

plagiotriaene

Three unbranched, equal-length rays are directed outward from a longer main spine and curve away from one another.

plagiodichotriaene

Three branched, equal-length rays are directed outward from a longer main spine.

diplagiodichotriaene (Plate 2, Fig. 4)

Similar to plagiodichotriaene, but instead of a simple long main spine another branching structure occurs. orthodichotriaene

Three branched equal-length rays meet at $120^{\circ}$ to each other and at $90^{\circ}$ to the third ray, which is greatly reduced.

desmas

Irregular, root-shaped spicules.

Monaxons (Plate 1, Fig. 1)

style

Straight or slightly curved rod, rounded at one end and pointed at the other.

subtylostyle

Straight or slightly curved rod, with an indistinct knob tylostyle at one end and a point at the other.

Straight or slightly curved rod, with a knob at one end and a point at the other. May be smooth or spined.

oxea

Slightly curved rod with points at either end. May be smooth or spined. toxon

Similar to oxea, but has a more distinct bend in the spicule.

strongyle

Slightly curved rod, rounded at both ends. May be smooth or spined.

tylote

Slightly curved rod with knobs at either end; may be smooth or spined.

Microscleres

spheraster

Rounded form with few large pointed projections covering the surface.

sterraster

Rounded, spherical form having many small pointed projections.

rhax

Rounded, bean-shaped body having numerous small projections.

Orosphaerid (radiolarian) or sponge fragments(?)

"branches" (Plate 2, Fig. 3; Plate 3, Fig. 4)

Long, thin, siliceous multiple-branched rods, usually solid-appearing (no axial canals visible).

mesh (Plate 3, Fig. 4)

Irregular mesh having no definite pore shape or pattern, usually slid-appearing (no axial canals visible).

curved spine, rough (Plate 3, Fig. 1)

Thick curved spine having a roughened surface; may terminate in a fragment of mesh.

straight spine, rough

Straight spine having roughened surface; may terminate in a fragment of mesh. 


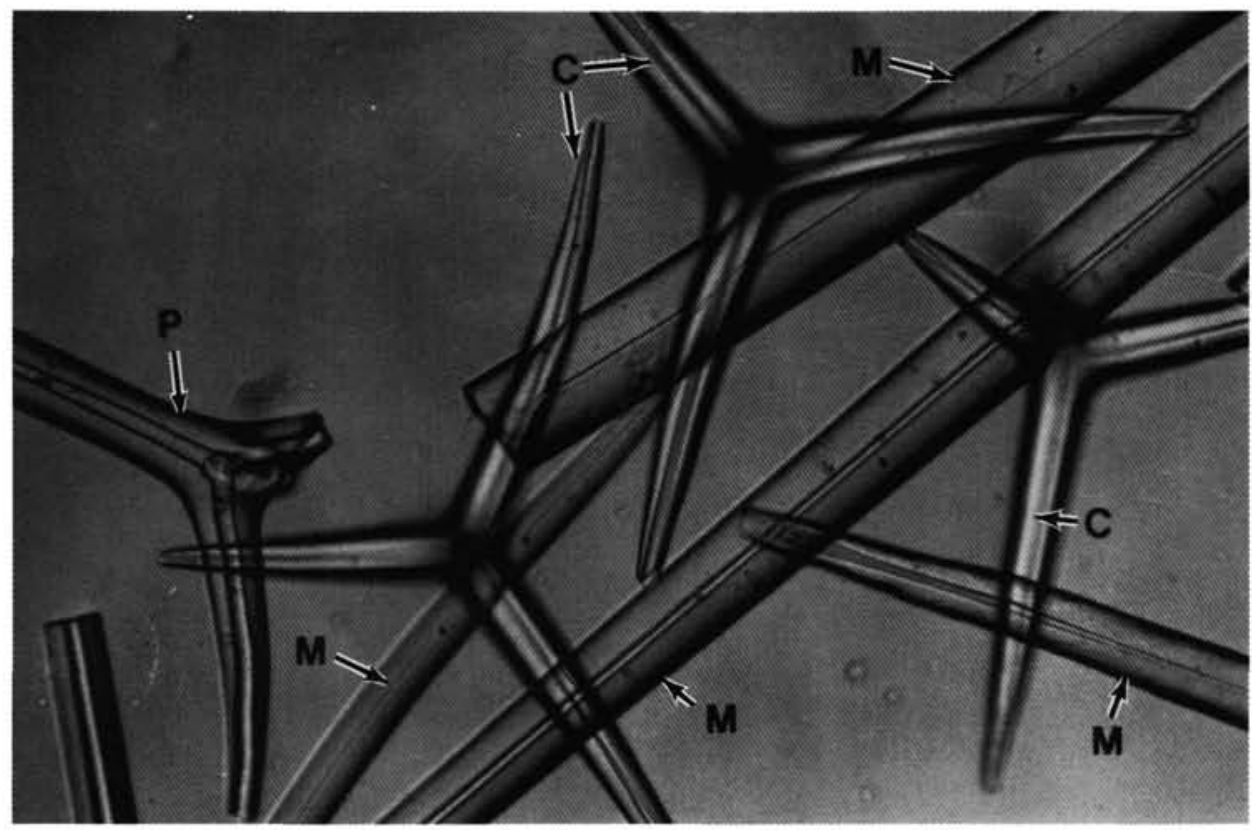

1

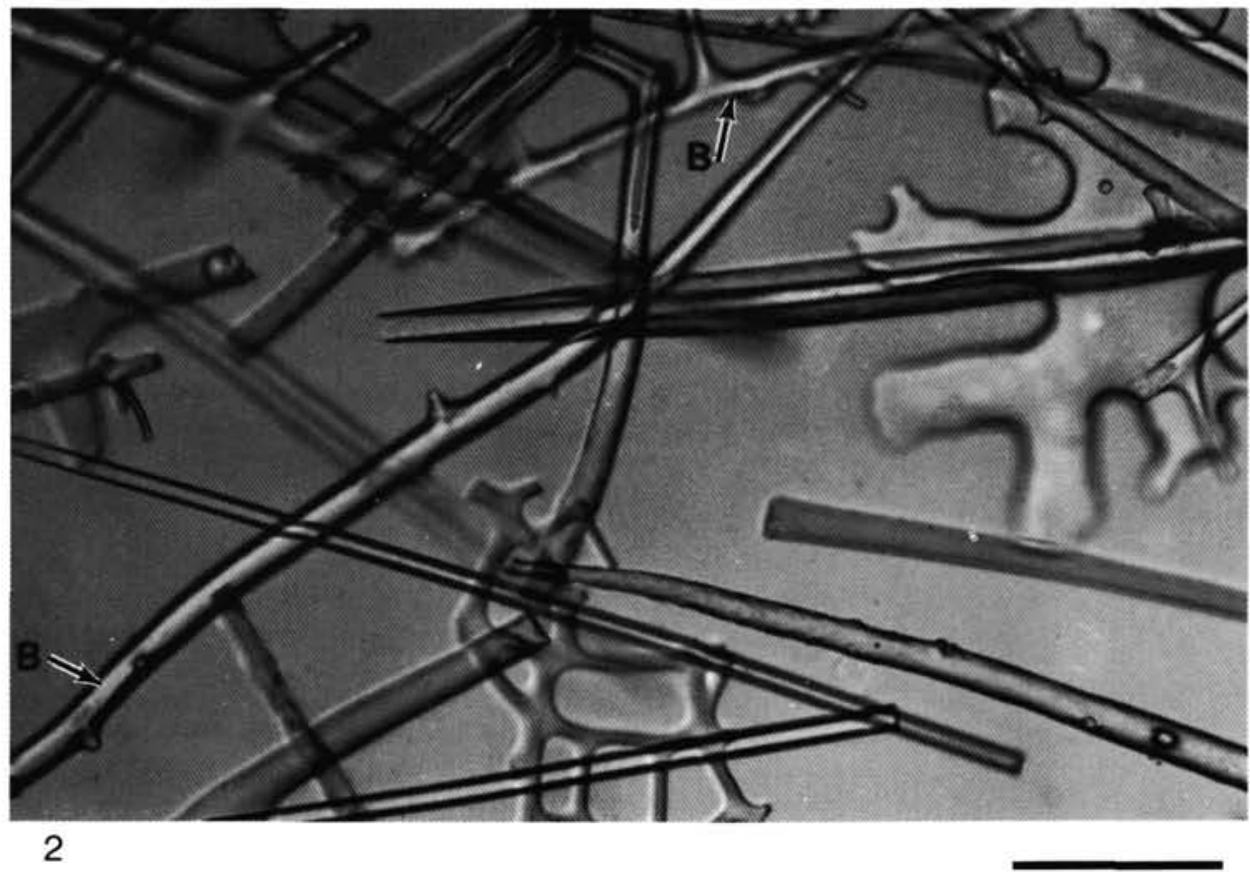

Plate 1. Comparison of middle Miocene with Oligocene siliceous sponge spicule assemblage, Site 628. Scale bar equals $100 \mu \mathrm{m}$. 1. Sample 101-628A$14 \mathrm{H}-4,106-108 \mathrm{~cm}$. Middle Miocene assemblage containing predominantly calthrops $(C)$, with plagiotriaenes $(P)$ and monaxons $(M)$. 2. Sample 101$628 \mathrm{~A}-18 \mathrm{H}-1,105-107 \mathrm{~cm}$. Oligocene assemblage from foraminifer-nannofossil ooze containing predominantly branches $(B)$ with tetraxons and monaxons. 


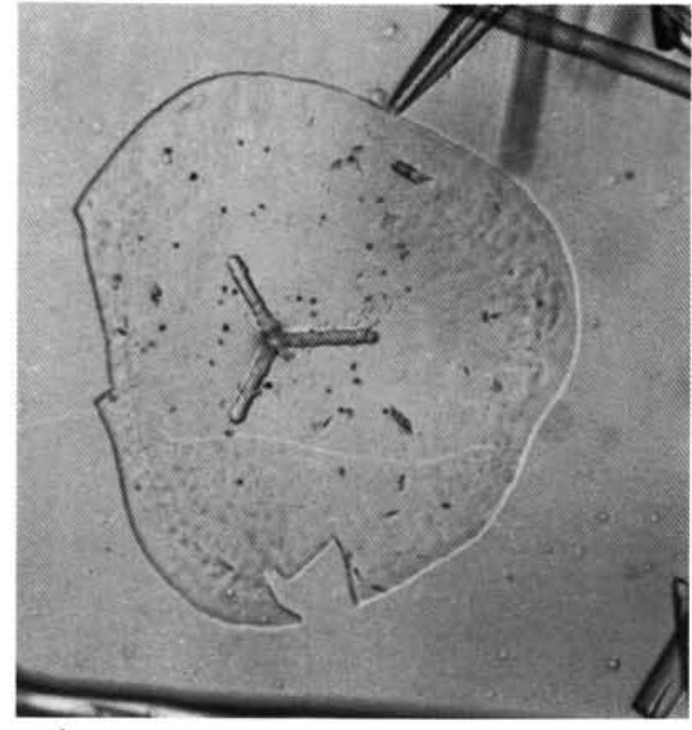

1

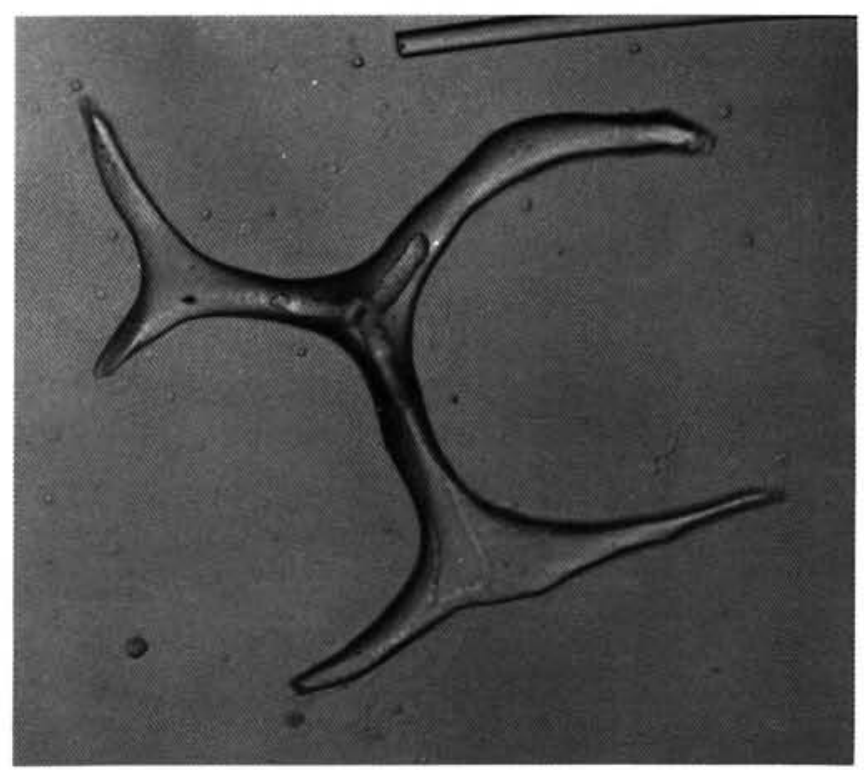

2
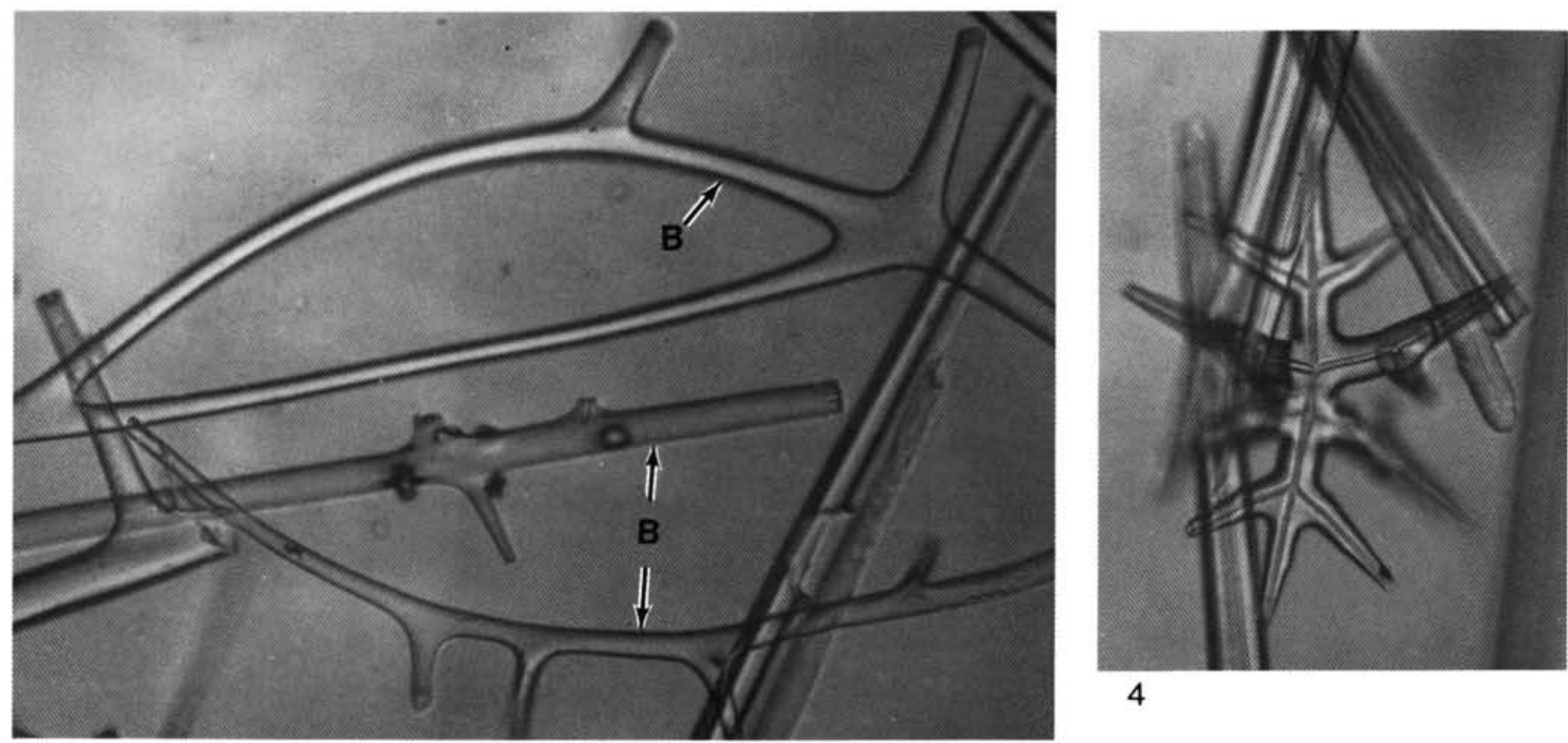

4

3

Plate 2. Oligocene and middle Miocene siliceous sponge spicules from Site 628. Scale bar equals $100 \mu \mathrm{m}$. 1. Sample 101-628A-18H-1, 105-107 cm. Phyllotriaene; Oligocene. 2. Sample 101-628A-19H-1, 50-52 cm. Phyllotriaene; Oligocene. 3. Sample 101-628A-18H-1, 105-107 cm. Branches (B); Oligocene. 4. Sample 101-628A-15H-3, 100-102 cm. Diplagiodichotriaene; middle Miocene. 

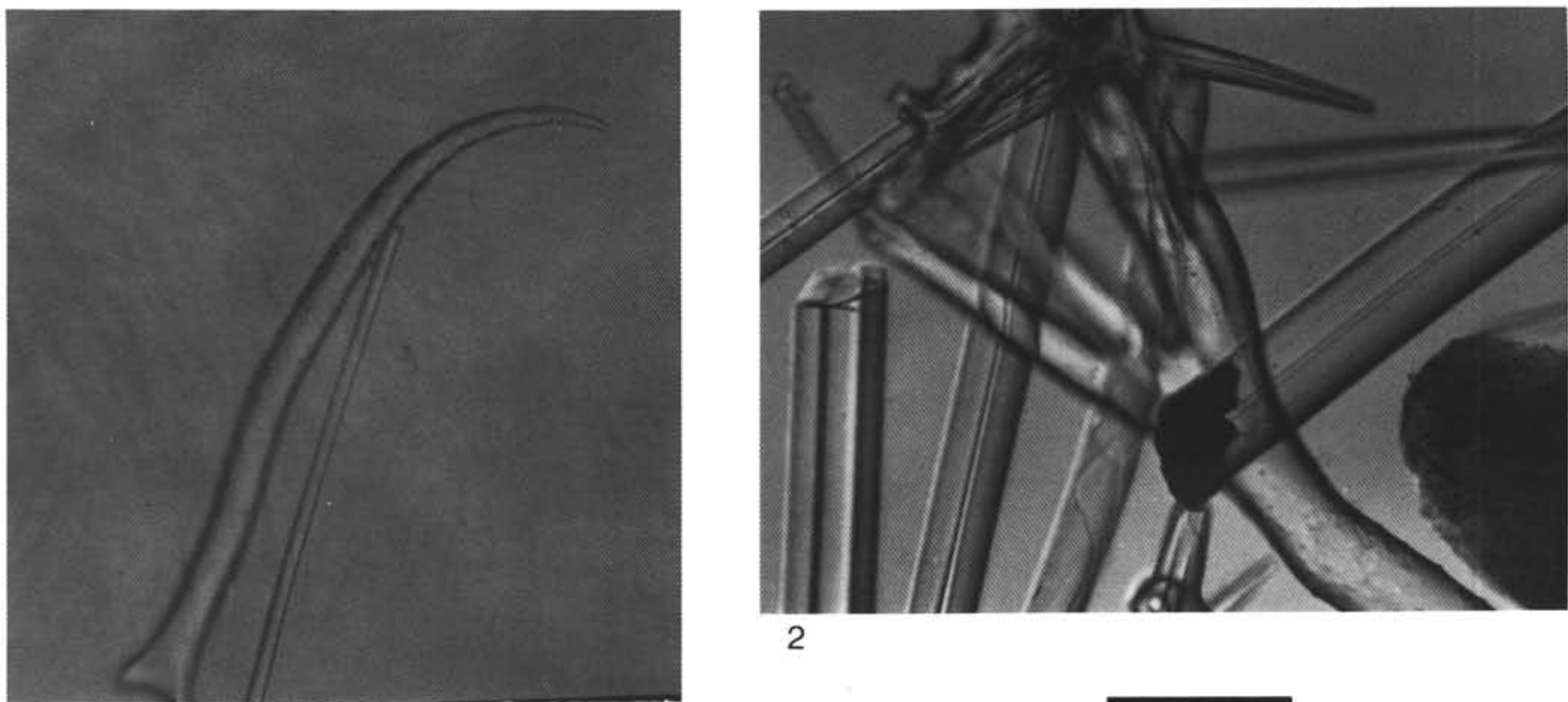

2

1

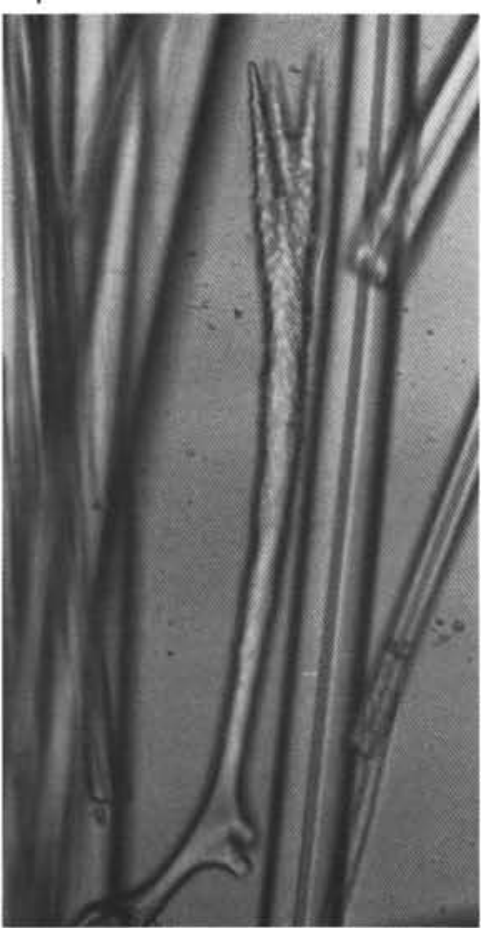

3

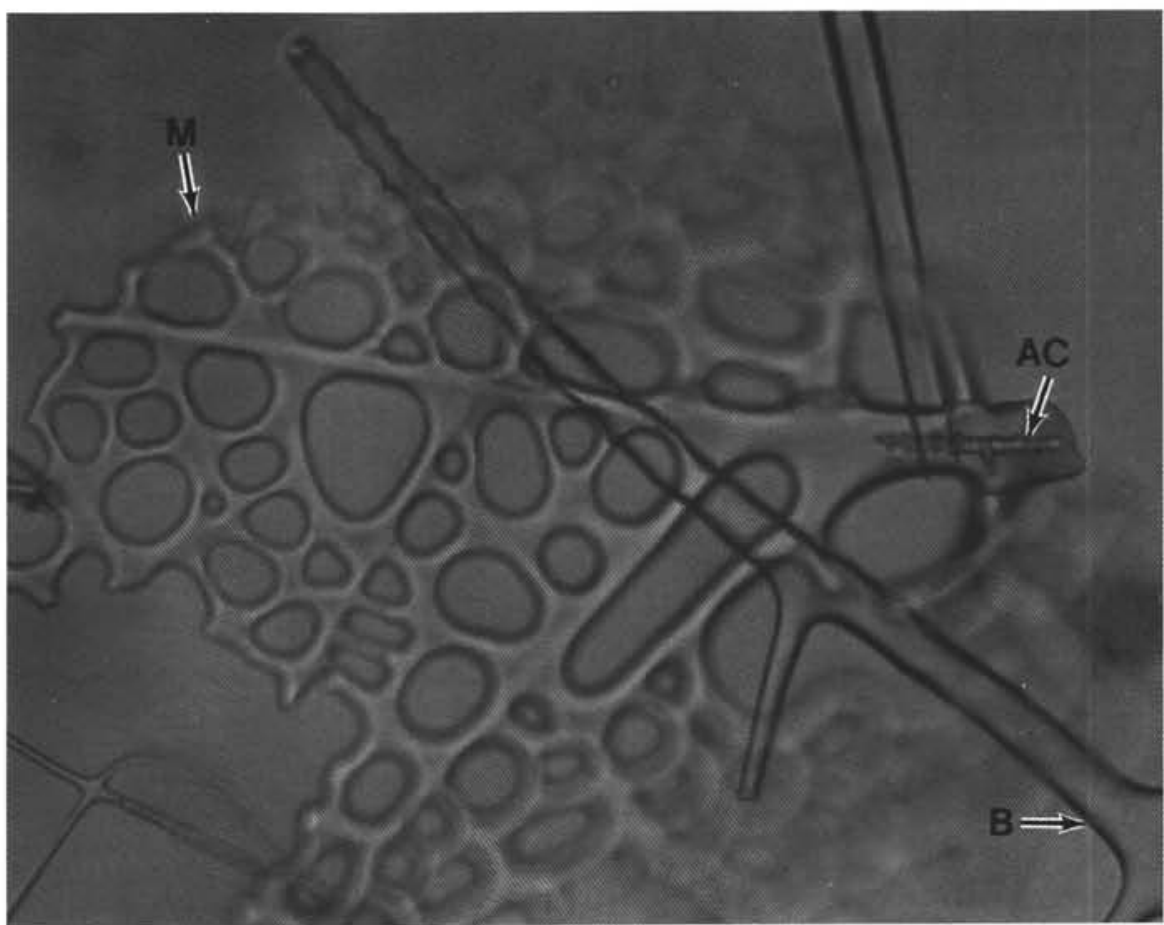

4

Plate 3. Oligocene and middle Miocene sponge or orosphaerid radiolarian fragments from Site 628 . Scale bar equals $100 \mu \mathrm{m}$. 1. Sample 101$628 \mathrm{~A}-19 \mathrm{H}-1,50-52 \mathrm{~cm}$. Curved spine, rough. 2. Sample 101-628A-15H-3, 100-102 cm. Large, digitally branched spine, probably an orosphaerid (radiolarian) fragment. 3. Sample 101-628A-15H-3, 100-102 cm. Smaller digitally branched spine, probably an orosphaerid (radiolarian) fragment. 4. Sample 101-628A-18H-1, 105-107 cm. Mesh $(M)$ and branch $(B)$. Note axial canal $(A C)$. 


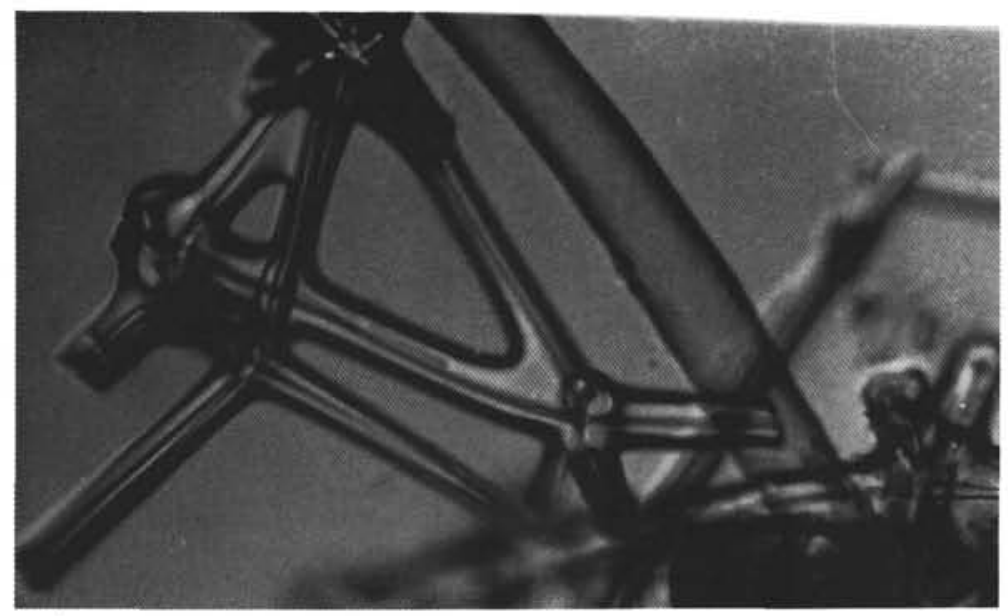

1

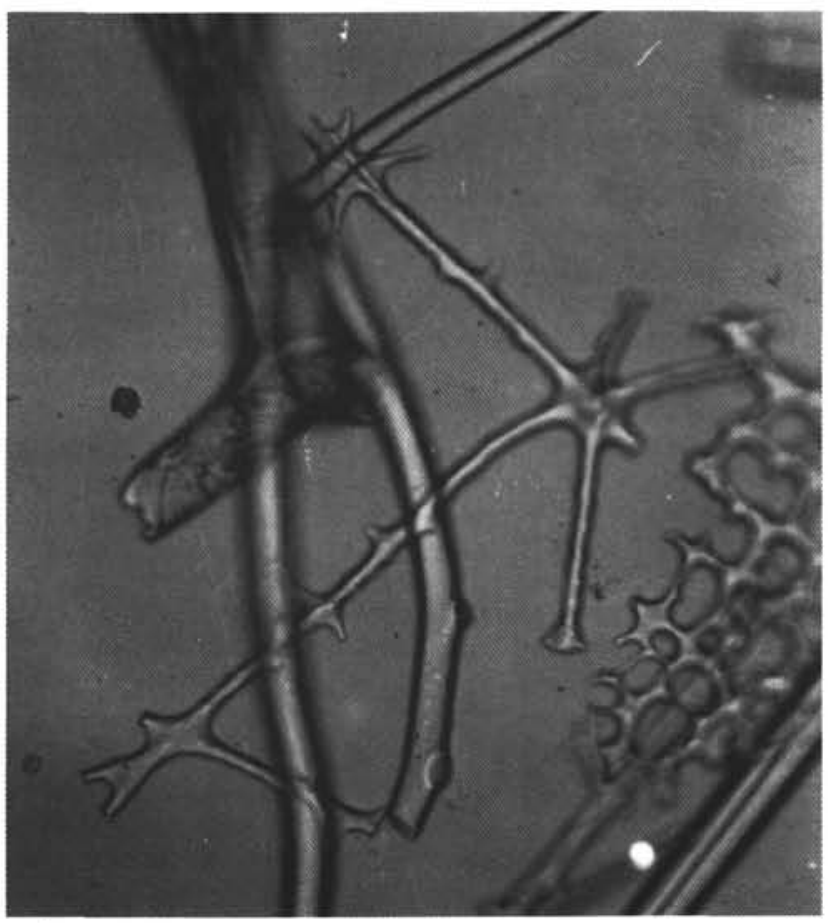

3

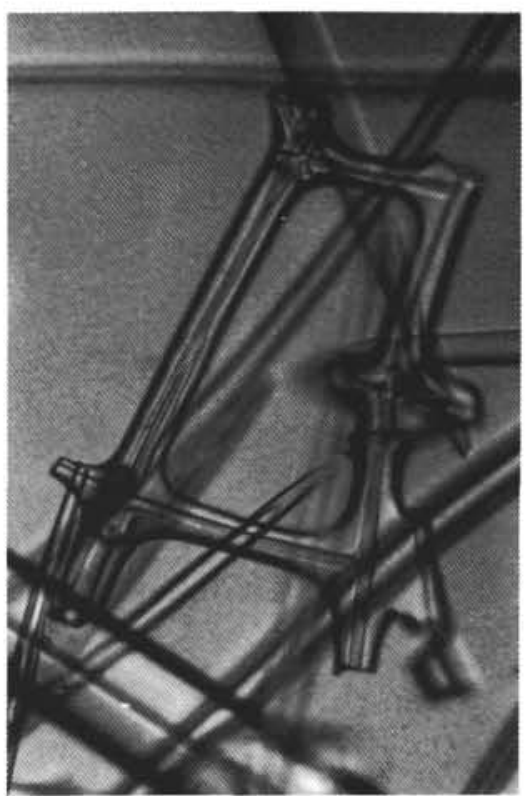

2

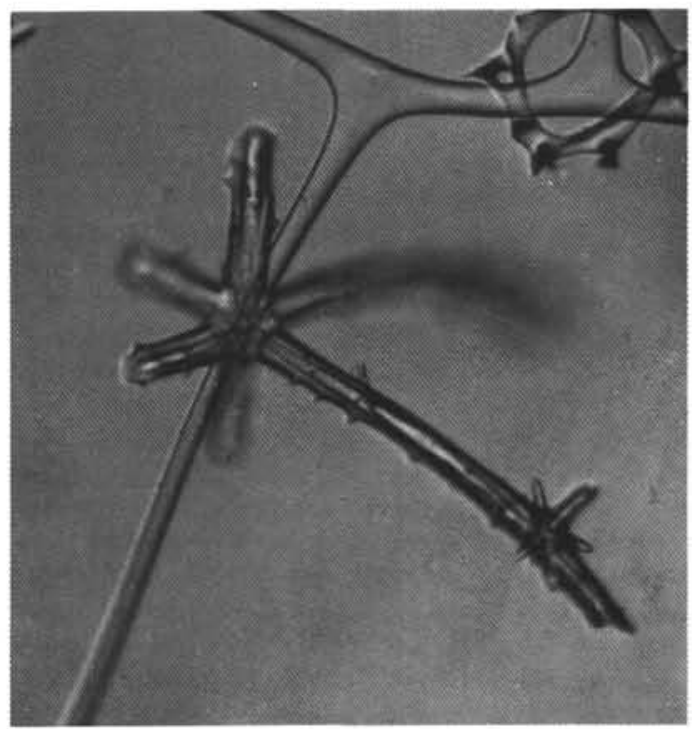

4

Plate 4. Oligocene and lower Miocene triaxonal (hexactinellid) siliceous sponge spicules from Sites 627 and 628 . Scale bar equals $100 \mu \mathrm{m}$. 1, 2. Sample 101-627B-19X, CC. Dictyonine fragments. 3, 4. Sample 101-628A-19H-1, 50-52 cm. Triaxonal (hexactinellid) fragments. 